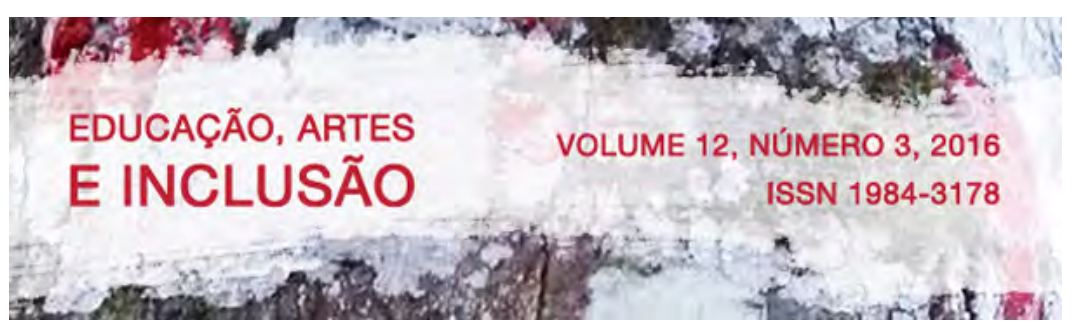

\title{
ARTE, LOUCURA E ENSINO: POR UMA ARTE/EDUCAÇÃO INCLUSIVA
}

\section{ART, CRAZINESS AND EDUCATION: FOR AN INCLUSIVE ART EDUCATION}

DOI: http://dx.doi.org/10.5965/1984317812032016123

Carlos Carvalho Macêdo - UFMA

Janine Alessandra Perini - UDESC

\begin{abstract}
RESUMO
Neste artigo refletimos sobre a definição da arte e as produções artísticas de pessoas diagnosticadas com alguma deficiência intelectual, afirmando seus valores artísticos e estéticos. Ao longo da pesquisa buscamos problematizar o conceito de arte apreendido, para então entendermos as variadas visões que a loucura e o louco receberam ao longo do tempo, utilizando as contribuições de Foucault (1972). No que diz respeito às produções artísticas, trouxemos as contribuições de autores versados sobre a iniciativa de Nise da Silveira, tais como Castro e Lima (2007) e Carvalho e Amparo (2006). Como resultado percebemos o quão é arbitrário e subjetivo qualquer conceituação sobre a arte, o objeto artístico e até mesmo o próprio fazer artístico. Nas considerações finais apresentamos que desconsiderar as produções artísticas das pessoas com deficiência intelectual é reiterar o processo de exclusão ao qual são submetidas.
\end{abstract}

PALAVRAS-CHAVES: Arte. Loucura. Educação. Inclusão.

\begin{abstract}
In this article we reflect about the definition of art and the artistic production of people diagnosed with some kind of disorder or mental illness, in order to affirm their artistic and aesthetic values. During the whole period of this research we problematized the comprehended concept of art in order to understand the various visions that craziness and the crazy people themselves have received during this period of time, taking in consideration the contributions of Foucault (1972). Regarding the artistic production, we brought contributions from authors that talk about the initiative of Doctor Nise da Silveira, such as Castro e Lima (2007) and Carvalho e Amparo (2006). As a result, we could observe how arbitrary and subjective any conceptualization of art, artistic object or even the own artistic process can be. In the final consideration we present that, disregard the artistic production of people with mental disorders is the same as reiterate the deletion process to which they are submitted.
\end{abstract}

KEYWORDS: Art. Madness. Education. Inclusion. 


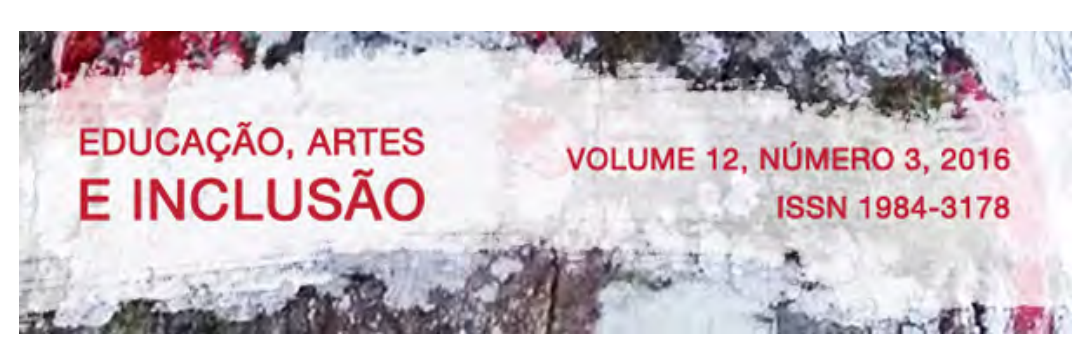

harmonia na distribuição de tais proporções gera-se um sentimento oposto ao da beleza, a fealdade, conforme explicita o autor.

No entanto, Read (1978) confronta sua própria teoria ao afirmar que nós fazemos um uso errôneo entre as palavras arte e beleza, uma vez que "[...] supomos que tudo quanto é belo é arte ou que toda arte é bela, que o que não é belo não é arte e a fealdade é a negação da arte" (READ, 1978, p.21). Como exemplo de contestação às teorias fechadas e restritas, temos as obras dos surrealistas e dadaístas, para citar apenas algumas correntes, que não obedeciam, em grande parte, à harmonia entre a forma, superfície e massa, tornando suas obras muitas vezes "desagradáveis" no processo de apreciar, mas que, não obstante, ganharam o status e são reconhecidas como obras de arte. Compreendemos, então, que agradar ou desagradar é algo muito subjetivo, que depende de pessoa para pessoa, sob o prisma das experiências de vida de cada um.

Na obra O que é arte, Jorge Coli (1995), de maneira bem didática, nos direciona a uma possível resposta para a nossa pergunta-chave. Contudo vemos que o que ele quer, na verdade, é nos pôr a pensar sobre o quão é arbitrário qualquer que seja a definição, conceituação ou teorização sobre o que seja arte. “[...] se pedirmos a qualquer pessoa que possua um mínimo contacto com a cultura ${ }^{4}$ para nos citar alguns exemplos de obras de arte ou de artistas, ficaremos certamente satisfeitos" (COLI, 1995, p.7). Como descrito, o autor esclarece que por mais que não saibamos qual o conceito de arte, nós sabemos identificar uma obra de arte e seus artistas.

Coli (1995) afirma que a ideia de arte muito tem a ver com o sentimento admirativo que temos sobre as produções artísticas. Em razão disto, o autor conceitua arte como "[...] certas manifestações da atividade humana diante das quais nosso sentimento é admirativo" (COLI, 1995, p.8). Desse ponto de vista, ele, ao mesmo tempo em que conceitua a arte, sugere um certo comportamento - o de admiração - que as pessoas têm que ter sob toda produção artística, e que, conforme pressupõe o autor, determina se a produção/obra é ou não arte. Todavia, em seguida, o autor refuta tal concepção, pois da mesma forma que para Read (1978) as formas agradáveis mantêm relação com o sentimento de beleza, para Coli (1995) a

\footnotetext{
4“'A palavra cultura é empregada não no sentido de um aprimoramento individual do espírito, mas do "conjunto complexo dos padrões de comportamento, das crenças, instituições e outros valores espirituais e materiais transmitidos coletivamente e característicos de uma sociedade', para darmos a palavra ao Novo Aurélio" (COLI, 1995, p.8).
} 


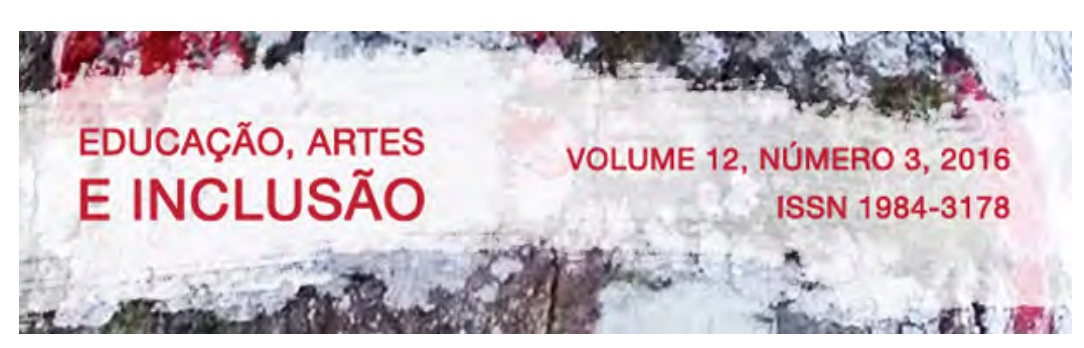

admiração mantém relação com este mesmo sentimento, visto que usa a obra de Marcel Duchamp, A fonte (1917), como exemplo para contestar sua concepção.

De acordo com Coli (1995), a obra de Duchamp não corresponde exatamente à ideia que o mesmo faz de arte. Ao observar essa obra de arte podemos notar que ela 'não agrada', como afirmou Read (1978) em sua definição de arte, e nem tampouco, suscita-nos um sentimento admirativo, como aborda Coli (1995). Pelo contrário, ao contemplá-la ficamos escandalizados e chocados, pois em nosso imaginário, e como já visto anteriormente, a ideia que temos de arte é ligada à beleza, à proporção harmônica das formas e não a algo banal em nosso dia a dia.

Pensando sobre o impacto que a obra $A$ fonte causa ao longo dos anos, encontramos em Tatarkiewicz (1971) uma definição de obra de arte que emoldura muito bem o feito de Duchamp. Para o teórico “[...] uma obra de arte é a reprodução de coisas ou a construção de formas ou a expressão de experiências tais que seja capaz de suscitar prazer ou emoção ou choque" (TATARKIEWCZ, 1971, p. 148). Dentro desse último parâmetro, compreendemos que a famosa obra de Duchamp causou tanto impacto que repercute até hoje, tornando-se uma das obras símbolos de uma corrente artística vista e estudada nos materiais didáticos de arte das escolas, dando valor ao feito marcante do artista e ao que ele se propusera fazer.

Porém, a nossa questão maior não cessa por aqui. Fischer explica que "[...] o trabalho para um artista é um processo altamente consciente e racional, um processo ao fim do qual resulta a obra de arte como realidade dominada, e não [...] um estado de inspiração embriagante" (FISCHER, 2014, p. 14). Assim como Tatarkiewicz (1971), Fischer (2014) traz uma concepção um tanto restrita à definição de arte ao considerar o fazer artístico apenas como um processo altamente consciente e racional, tendo que o artista ter em mente que faz uma obra de arte, caso contrário toda produção é desconsiderada como tal.

A respeito dessa realidade dominada, Fischer (2014) caracteriza o artista como alguém que precisa ter domínio sobre as técnicas, regras, recursos, formas e convenções próprias do fazer artístico, como se isto fosse o quesito primordial e exclusivo para considerá-lo artista.

Com base nesta perspectiva do autor, revelaram-se algumas das outras indagações levantadas por nós anteriormente. Por exemplo: por que o artista é considerado um artista somente se tiver o propósito de fazê-la ou se tiver o domínio das técnicas próprias ao fazer 


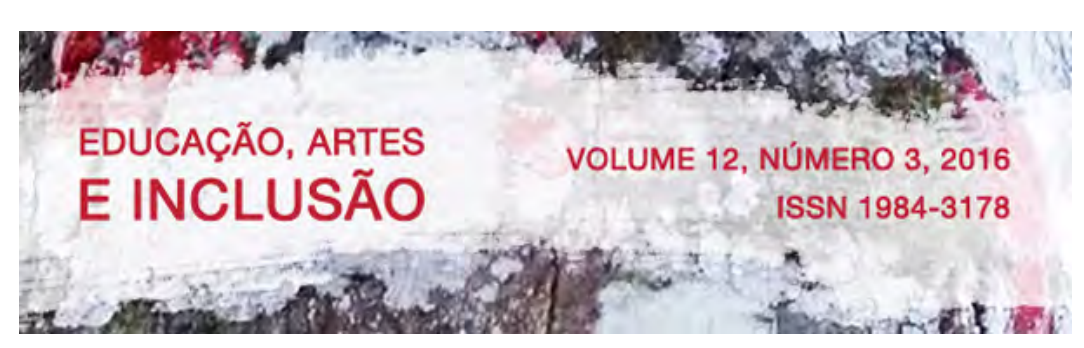

artístico? Em consonância com todas essas problemáticas apresentadas, surge outra questão tão difusa quanto a primeira e que requer um pouco de nossa atenção. Como abordar conceitos/definições de arte limitados em sala de aula sem descaracterizar a diversidade das produções artísticas do país e do mundo?

Diante dessa interrogativa, faremos um percurso histórico sobre o ensino de artes, trazendo algumas das contribuições de Ana Mae Barbosa ao desenvolvimento da Arte/Educação no país.

\section{ENSINO DA ARTE NAS ESCOLAS}

Para este debate, queremos suscitar uma reflexão diante das diversas abordagens e roupagens a que a arte é submetida em épocas distintas. Concordamos com os Parâmetros Curriculares Nacionais de Arte (PCNs), quando esclarecem que "[...] a dimensão social das manifestações artísticas revela modos de perceber, sentir e articular significado e valores que orientam os diferentes tipos de relações entre os indivíduos na sociedade" (BRASIL, 1998, p.19). Considerando as diversas correntes artísticas como o classicismo, o romantismo e o modernismo, os ideais sobre o que é arte são diferentes, uma vez que os valores, crenças e costumes da sociedade mudam em cada uma dessas épocas e todo o contexto social, político, econômico e cultural influencia no modo de fazer e apreciar a arte.

Ainda nos PCNs, compreendemos que o trabalho com as artes (Artes Visuais, Dança, Teatro e Música) é pensado para formação de cidadãos, contribuindo para o desenvolvimento da identidade do indivíduo como ser coletivo, visto que ele é parte integrante da sociedade e, também, ser particular, considerando seus anseios e angústias pessoais.

Sobre a perspectiva do trabalho do Arte/Educador, em sala de aula, observamos nos PCNs como o trabalho docente deve ser pensado. No trecho: “[...] o aluno desenvolve sua cultura de arte fazendo, conhecendo e apreciando produções artísticas” (ibid., p.19). No texto evidenciamos os verbos no gerúndio, entendendo que no interior de cada um encontra-se um direcionamento de como o Arte/Educador deve pensar sua prática para ajudar seu aluno na compreensão, na reflexão e no fazer arte. 


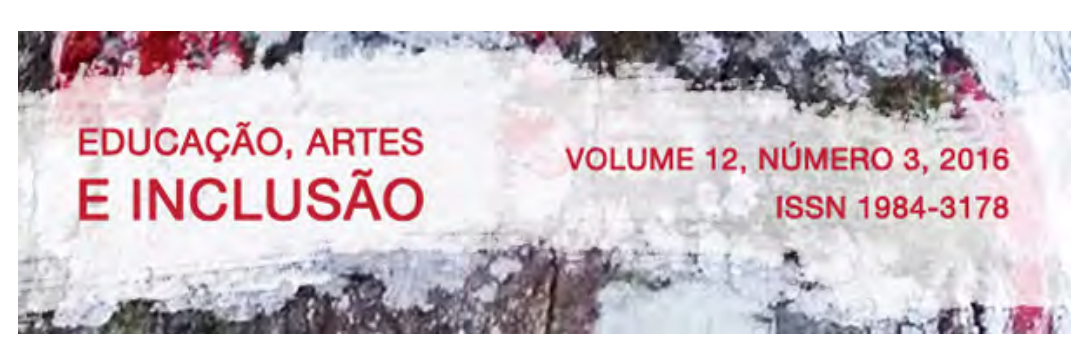

O professor como mediador desse diálogo, levantando questões críticas, e, o aluno como agente pensante, refletindo sobre estas questões e revelando outras tantas que poderão surgir, propondo assim um debate construtivo onde ambas as partes (professor e aluno) constroem o conhecimento.

Ana Mae Barbosa, a sistematizadora desta tríade prático-conceitual (conhecer, fazer e apreciar), nomeou-a de Abordagem ou Proposta Triangular, afirmando que:

A Proposta Triangular foi sistematizada a partir das condições estéticas e culturais da pós-modernidade. A pós-modernidade em arte/educação caracterizou-se pela entrada da imagem, sua decodificação e interpretação na sala de aula $[\ldots]$ (BARBOSA, 2008, p.13).

Para a autora, compara-se o ensino de arte sem o uso da imagem ao o de ensinar a ler sem livros. No entanto, lembramos que até a chegada da pós-modernidade, o ensino de arte passou por muitos entraves políticos e sociais.

Em Recorte e colagem: influência de John Dewey no ensino da arte no Brasil, Barbosa (1982) faz um panorama histórico da Arte/Educação no Brasil em paralelo à educação geral do país. Podemos perceber, na obra, que o ensino da arte não recebia a devida atenção por parte da sociedade e até mesmo por alguns dos profissionais envolvidos na área. O ensino da arte foi relegado a atividades de recreação, passatempo (literalmente) ou, especialmente, em eventos festivos, recebia uma atenção meramente decorativa, como explicita a autora em seus estudos.

A promulgação da Lei $n^{0}$ 5.692/71, Lei das Diretrizes e Bases Nacionais (LDB), que tornou obrigatório o ensino de artes nas escolas e viabilizou, por conseguinte, a criação de cursos superiores no país, foi uma notável conquista para os Arte/Educadores. Contudo, como analisado por Barbosa (1982), os cursos oferecidos pelas universidades pretendiam formar em dois anos um professor que era obrigado a ensinar, ao mesmo tempo, Artes Visuais, Música e Teatro a alunos da primeira a oitava série (atual $1^{\circ}$ ao $9^{\circ}$ ano). Percebemos que os almejados cursos superiores cumpriam a simples função de preencher a demanda de mão-de-obra, exigida em lei, porém, sem estar necessariamente vinculados ao real compromisso com o desenvolvimento da Arte/Educação do país. 


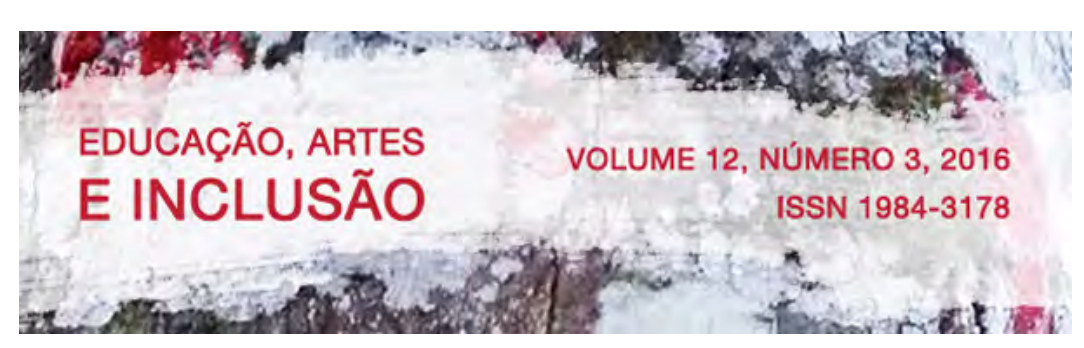

Passados alguns anos da promulgação da lei, a criação dos cursos superiores na área de arte passou de dois para quatro anos, havendo uma crescente valorização no perfil do profissional formado e nas metodologias. Mas, nas escolas ainda se encontrava a livre expressão, influenciada pela teoria da psicologia, que valoriza as percepções e o desenvolvimento cognitivo e motor da criança. No entanto, aponta Barbosa (1982; 1989), esta crescente valorização da livre expressão foi se diluindo em práticas desconexas e ineficientes, no que diz respeito ao desenvolvimento intelectual e crítico da criança na área das artes.

Com a chegada da Pós-modernidade, o mundo passa a experimentar mudanças profundas, ocasionadas por crises políticas, econômicas e sociais, ganhando o ensino de arte outra conotação. Devido às diversas tensões políticas e sociais, o ensino pela imagem tornouse muito mais profícuo na Arte/Educação, visto que com ela o aluno desenvolveria sua sensibilidade. Sensibilidade, de acordo com Barbosa (2008), entendemos ser o desenvolvimento dos sentidos, pois é aguçando-os que a arte transmite significados que não podem ser transmitidos por meio de nenhum outro tipo de linguagem. O uso da imagem é uma forma de conhecer a cultura e a história de um povo.

\begin{abstract}
Preparando-se para o entendimento das artes visuais se prepara o observador para o entendimento da imagem quer seja arte ou não [...] Temos que alfabetizar para a leitura da imagem. Através da leitura das obras das artes plásticas estaremos preparando a criança para a decodificação da gramática visual [...] esta decodificação precisa ser associada ao julgamento da qualidade do que está sendo visto aqui e agora e em relação ao passado [...] Sem conhecimento de arte e história não é possível à consciência de identidade nacional [...] (BARBOSA apud RIZZI, 2008, p. 337).
\end{abstract}

De fato, levar o aluno ao contato direto (ou indireto) com a obra de arte, permite que o aluno conheça mais o mundo das imagens e a relação que mantém com o seu mundo externo (a sociedade que o cerca) e interno (seus pensamentos, ideias, credos, etc.). Seria a partir de uma atitude artística e estética consciente que o professor poderia proporcionar a seu aluno uma aproximação ao legado cultural e artístico, permitindo-lhe, assim, que conheça e elabore saberes práticos e teóricos sobre arte, conforme explicita Ferraz e Fusari (1992). As autoras também apontam que, a excelência no ensino da arte necessita que o professor, como mediador artístico e cultural, ajude seu aluno a elaborar uma cultura estética e artística, melhorando suas sensibilidades e saberes práticos e teóricos em arte. 


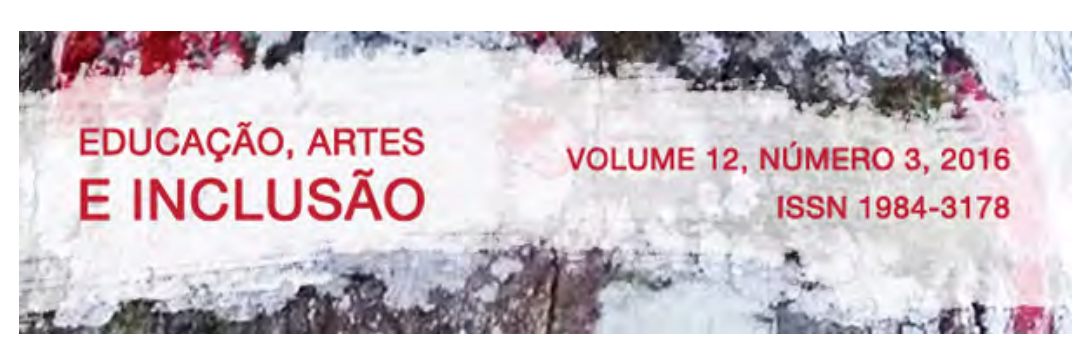

A arte propicia ver o outro e a nós mesmos, pois à medida que nela percebemos traços de uma realidade distante, vemos, também, nuances individualizantes que nos atingem de maneira particular. Nessa perspectiva, toda produção, seja ela verbal ou não verbal, se interrelaciona com o mundo que nos cerca. Nada é criado isoladamente.

No tocante às obras de Barbosa, asseveramos que a autora luta por um ensino de arte como cultura, pois, como ela mesma justifica, é por meio da arte que podemos visualmente conhecer os costumes, crenças, valores políticos, econômicos e sociais de um povo. A autora acredita que "A arte na educação, como expressão pessoal e como cultura, é um importante instrumento para a identificação cultural e o desenvolvimento individual" (BARBOSA, 2008, p.99).

A autora quer que sejamos críticos diante das produções, refletindo acerca não somente da obra, mas também do meio em que ela está inserida, pois, tudo está intrinsecamente interligado, em constante diálogo. Para a autora, ao falarmos de excelência no ensino da arte "[...] estamos falando não somente sobre as qualidades e significados de trabalhos dos grandes artistas e da experiência que eles podem proporcionar, mas também da postura diante da realização artística em geral” (BARBOSA, 2013, p.132).

Barbosa (2013) ressalta que há um estado geral de desorganização no ensino das artes, com ênfase excessiva no fazer artístico e ênfase mais do que insuficiente no estudo das artes como objeto cultural. Essa desorganização, pontuada pela autora, é apenas um reflexo de como a arte vem sendo encarada há muito tempo, uma vez que, muitos estudiosos e profissionais da educação alegavam que a arte não poderia ser considerada disciplina no currículo base da escola, porque não tinha um programa de conteúdos definido. Contrapondose a tal alegação, os Arte/Educadores trouxeram um leque de conteúdos que poderiam ser trabalhados em sala de aula.

A arte "[...] é um dos importantes meios pelos quais as potencialidades intelectuais tornam-se habilidades intelectuais à medida que damos a estas capacidades oportunidade de funcionar" (EISNER, 2013, p.126). A arte permite que o aluno/indivíduo experimente, sinta, desenvolva e aprecie de maneira a conectá-lo a seu mundo exterior e interior. 


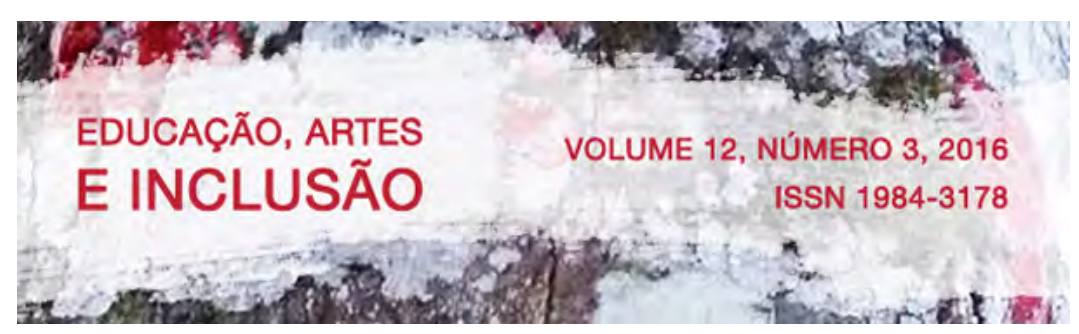

\section{O PROBLEMA DAS DEFINIÇÕES DE ARTE}

A razão de ser da arte nunca permanece inteiramente a mesma (FISCHER, 2014, p.16).

Retornando ao problema das definições de arte, nos deparamos com algumas arestas, que obtiveram nossa atenção por se mostrarem tão reducionistas ao ponto de desconsiderarem outras formas do fazer artístico. Encontramos em Coli (1995) uma possível resposta a esta e a todas as outras dúvidas apresentadas até então:

Para decidir o que é ou não arte, nossa cultura possui instrumentos específicos. Um deles, essencial, é o discurso sobre o objeto artístico, ao qual reconhecemos competência e autoridade. Esse discurso é que proferem o crítico, o historiador da arte, o perito, conservador de museu. São eles que conferem o estatuto de arte a um objeto (COLI, 1995, p. 10).

Levando em consideração essa afirmação, Coli aponta que, nossa sociedade dispõe de instrumentos que determinarão, por nós, o estatuto de arte a um objeto. De acordo com o autor, os museus e galerias são espaços em que certamente nos depararemos com obras de arte, porque, conforme Coli (1995), a sociedade designou a estes espaços a exposição e a manutenção de obras de arte. Outro ponto explicitado pelo o autor é o discurso sobre o objeto artístico, mostrando que este discurso é uma das principais, se não a mais eficaz ferramenta para classificar, nomear, cotejar um objeto como obra artística. Coli (1995) fala que a crítica distingue, por hierarquia, as obras de arte, o que quer dizer que os instrumentos culturais que nossa sociedade dispõe, sob o prisma da crítica de arte (discurso), intervêm na disposição relativa dos objetos artísticos, pretendendo incutir em nós que tal obra tem mais relevância que outra, que tal livro ou filme é melhor que outro, como descrito pelo autor.

Nessa tentativa de classificar as obras artísticas por uma ordem de excelências, o autor chama a atenção para o conceito de obra-prima, que originariamente tinha outra conotação, diferente da que compreendemos hoje. 


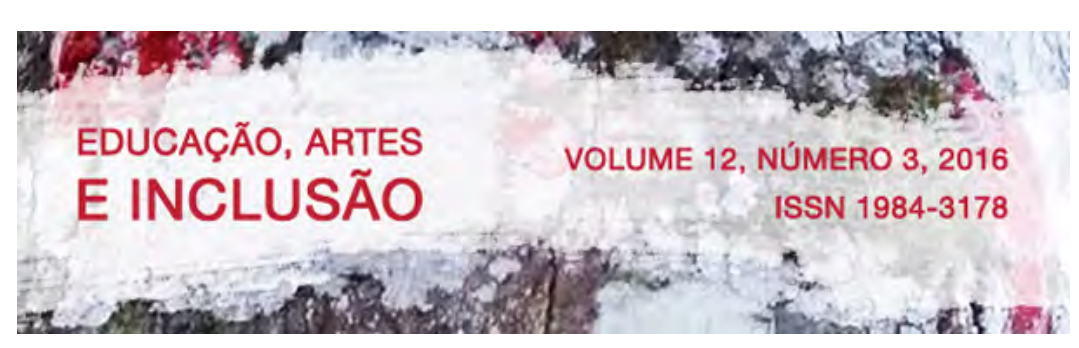

No passado [...] a obra-prima era aquela que coroava o aprendizado de um ofício, que testemunhava a competência de seu autor. Não se tratava de uma realização forçosamente inovadora, original, e era com frequência um produto utilitário, saído das mãos de um carpinteiro, ourives, tecelão (COLI, 1995, p. 14).

Como podemos notar, o significado, primeiro, dado ao termo obra-prima era destinado a excelência com que os artistas (ourives, tecelão, artesãos, etc.) executavam as técnicas e regras que aprenderam de seus mestres na construção de um objeto que, por muitas vezes, era um produto utilitário, como é o caso da mobília. Nesse contexto, as obras eram julgadas sob critérios precisos de fabricação. Se trouxermos o termo obra-prima para os nossos dias, os discursos sobre a arte consideram critérios mais subjetivos, incertos, que não apenas o do "saber fazer". Como pontuado por Coli (1995), muitos dos críticos de arte hoje não são artistas e não tem conhecimento sobre as técnicas do fazer artístico, diferentemente de quando o termo apareceu pela primeira vez. Para Fischer (2014):

Toda arte é condicionada pelo seu tempo e representa a humanidade em consonância com as ideias e aspirações, as necessidades e as esperanças de uma situação histórica particular. Mas, ao mesmo tempo, a arte supera essa limitação e, de dentro do momento histórico, cria também um momento de humanidade que promete constância no desenvolvimento (FISCHER, 2014, p.17).

O trabalho com a arte não deve ser apartado da realidade em que está inserido, pois, assim como a própria humanidade, a arte está em constante mudança, reciclagem e ressignificação. Pensando nisto, compreendemos que levar conceitos limitados sobre o que é arte e o fazer artístico para sala de aula é não permitir ao aluno perceber as mudanças e ressignificações que ela sofreu e ainda sofre com o passar do tempo. Essas mudanças revelam como a sociedade possibilita ao homem ver, sentir e ouvir o mundo a sua volta.

Essas reflexões nos valem pelo fato de termos passado por diversos movimentos artísticos, que nos proporcionaram visões diferentes sobre a arte, permitindo termos uma gama enorme de possibilidades artísticas. 


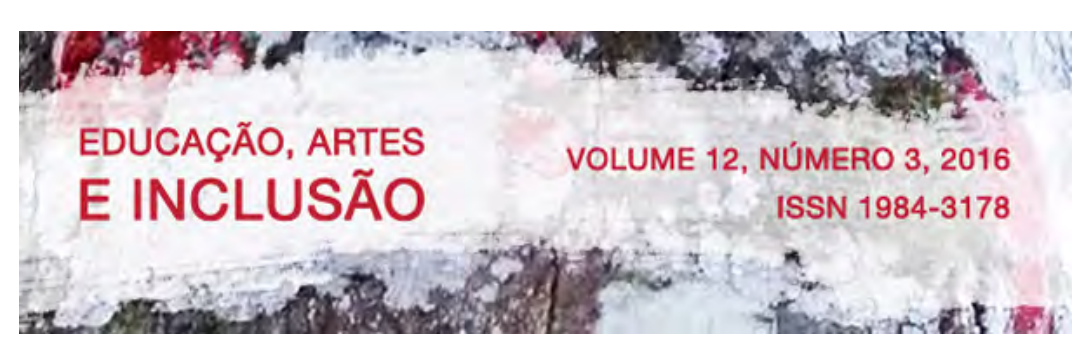

servindo como uma espécie de mensageiro das entidades paranormais, gerando desde então uma relação tênue entre adoração e execração, dependendo da sociedade a qual está inserido.

No entanto, ressaltamos que a figura do louco sempre é posta à margem da sociedade, se pensarmos que, com a palavra animismo, visto no trecho acima, o indivíduo louco é colocado em relação de igualdade com um animal, o que por sua vez é tido como um ser irracional, refletindo, consequentemente, uma certa inferioridade em relação ao ser humano, dotado do poder de raciocínio.

Entendendo o louco não como um ser humano, mas como uma "coisa", tiramos dele o que lhe é próprio, o direito de se fazer ouvir e manifestar seus pensamentos e opiniões acerca do que o circunda - estatuto de humanidade —, conforme destaca Frayze-Pereira (1984). Soçobramos, mais uma vez, ao que já foi dito anteriormente: o louco é um ser ignorado, excluído e marginalizado dentro do seio da sociedade ${ }^{6}$.

As contribuições de Foucault (1972) são de suma importância para entendermos a história da loucura e as variadas visões que ela recebeu em épocas distintas. Antes de nos apresentar a loucura, propriamente dita, Foucault (1972) se reporta à lepra na Idade Média, mais especificamente aos leprosários, que com o desaparecimento da doença ao final da época medieval, tornaram-se inabitáveis, estéreis e por muito tempo ligados ao "desumano". A doença era vista como a marca do poder supremo sobre o homem, que infligia e abusava de sua bondade, mostrando-nos, desse modo, o poder que a religiosidade, por meio da Igreja, tinha sobre a sociedade desta época. Nesse contexto, o caráter religioso tinha um efeito enorme sobre o comportamento das pessoas da época, com o clero detendo o poder em suas mãos neste período.

A exclusão a que eram submetidos não era uma atitude considerada irresponsável ou indiferente ao estado do indivíduo e, sim, um ato de compaixão e benevolência, pois, como pregava a Igreja, a doença era uma forma de punição divina pelos males que o indivíduo cometeu neste mundo e, para tanto, ele teria que suportar este calvário sozinho, conforme relata Foucault (1972).

\footnotetext{
${ }^{6}$ Situamos nosso debate no contexto ocidental, já que focalizamos o personagem em questão à nossa realidade e quanto aos nossos paradigmas que refletem o modo como concebemos a loucura e o louco perante a nossa sociedade.
} 


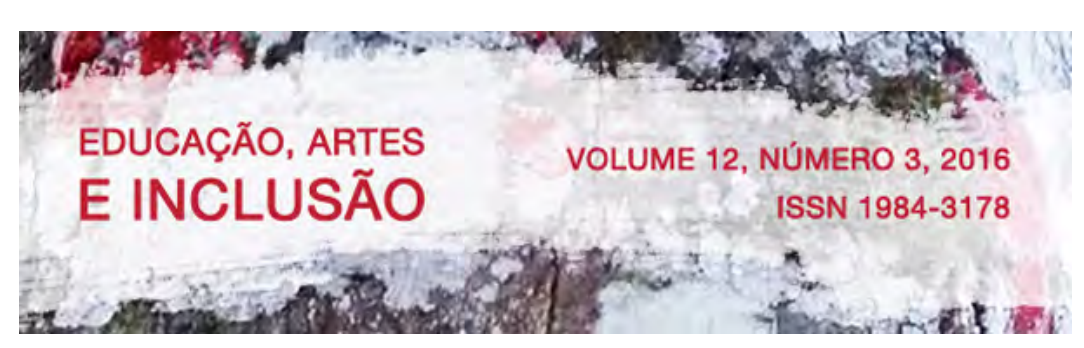

Todo este cenário e a criação de centros de depósito ${ }^{7}$, aos quais estavam destinados os leprosos, mais tarde serviriam aos "cabeças alienadas", que durante o período da lepra viviam nas ruas livremente, tendo uma "existência facilmente errante" (FOUCAULT, 1972, p.9). Sobre essa vida facilmente errante, localizados agora numa paisagem renascentista, o autor nos apresenta as condições em que os alienados viviam. Eles eram escorraçados de suas cidades e jogados em grandes embarcações, que os levavam para outras cidades, vivendo, então, em uma constante e interminável partida, pois as autoridades locais não queriam ter o trabalho de mantê-los em suas jurisdições.

Era comum na época encontrar, nos portos das cidades, embarcações lotadas por um aglomerado de "alienados". A respeito dessa situação, Foucault (1972) nos explica que a prática de submeter os loucos à mercê das incertezas da navegação era um ritual, que, além de servir aos propósitos da utilidade social ou segurança dos cidadãos, conotava em um sentido muito mais espiritual, porque confiando o louco às águas do mar estava-se com isso purificando sua pobre alma da decadência. Assim como em muitos rituais religiosos, a água é um símbolo da purificação, pois o ato de se banhar tiraria as impurezas e sujeiras do corpo, como mostra Chevalier e Gheerbrant (2015).

Nessa infinita partida e áurea mística, nosso personagem é construído não apenas em nosso imaginário, mas também na realidade que o subscreve. Um ponto tocado por Foucault (1972) em sua obra, que nos chamou atenção, é que a loucura era concebida dentro de uma hierarquia dos vícios, e do modo como fora apresentada pelo autor, compreendemos certa proximidade entre a loucura e um dos sete pecados capitais - a soberba - delatados pelo clero ${ }^{9}$.

Sobre esses vícios, que são condutas ou costumes condenáveis pela sociedade ${ }^{10}$, ressaltamos que a loucura, entendida como tal, nos leva a uma questão puramente social, pois, a partir do momento em que afirmamos que certas atitudes ou condutas ou costumes são

\footnotetext{
${ }^{7}$ Como ficou entendido na obra de Foucault, História da loucura na Idade Clássica (1972), inferimos que os leprosários serviam como centros prisionais, sem fins de tratamento ou assistência aos leprosos, atuando pura e simplesmente como meios de exclusão.

${ }^{8}$ Termo encontrado em Foucault (1972), referindo-se aos loucos.

9 “A loucura só existe em cada homem, porque é o homem que a constitui no apego que ele demonstra por si mesmo e através das ilusões com que se alimenta" (FOUCAULT, 1972, p.24).

${ }^{10}$ Significado extraído do dicionário Aurélio.
} 


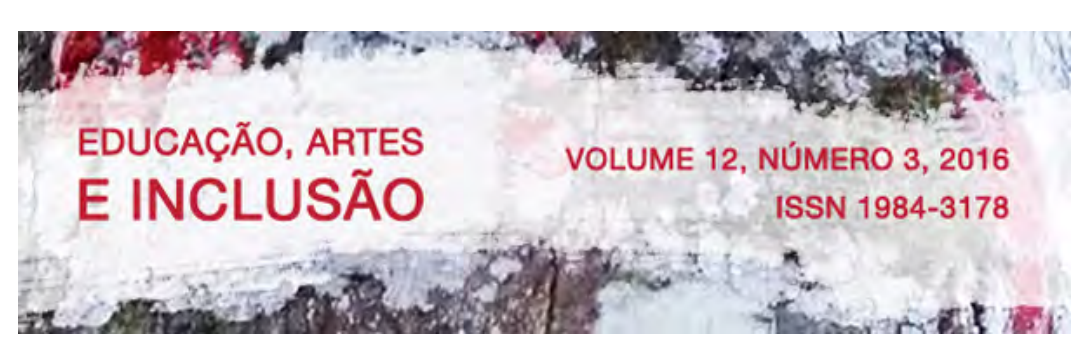

condenáveis pela sociedade, quer-se com isso pôr uma relação de justaposição entre uma atitude (coletiva), tida como válida, perante outra (individual), julgada como falha.

Adiante, em seu estudo, Foucault (1972) utiliza-se da literatura e das artes plásticas para elucidar e ilustrar o tratamento conferido às questões da loucura na Era Clássica. Em uma de suas explanações, ele recorre a uma obra de Bosch $^{11}$, A Nau dos Loucos (1450-1516), no intento de elencar alguns elementos visuais desta obra que corroboram com a construção da imagem que se tem, até hoje, sobre os loucos.

Vale notar que a loucura e o louco mantêm traços diferentes, mas não indissociáveis, pois, conforme apresentado pelo autor, sob uma visão literária, enquanto a loucura " [ ...] conduz todos a um estado de cegueira, onde todos se perdem, o louco, pelo contrário, lembra a cada um sua verdade [...]" (FOUCAULT, 1972, p.14).

Essa distinção entre o louco e a loucura, mostra-se de tal modo, que não se pode falar de uma sem expor as manifestações do outro, já que para a loucura ter razão de existir ela precisa se manifestar no indivíduo. No entanto, como assinalado em Frayze-Pereira (1984), notamos que muitas vezes a figura do louco ganha mais força que a própria loucura em si, por ele sofrer os percalços da loucura que o submete.

Na maioria dos estudos sobre loucura a que tivemos acesso, percebemos que o que se tem na verdade são estudos sobre o indivíduo louco e/ou suas experiências e sobre isso, Frayze-Pereira (1984) explicita que a loucura se mostra como uma vestimenta que o louco utiliza, transfigurando-o, geralmente, em um monstro que perde sua humanidade.

Mais adiante, munido de um discurso filosófico, Foucault (1972) põe em questão a relação conflituosa entre loucura e razão, afirmando que em ambas encontramos um pouco de cada uma. Ao utilizar as contribuições da tradição humanista, o autor diz que a loucura " [...] nasce no coração dos homens, organiza e desorganiza sua conduta" (FOUCAULT, 1972, p.28). Ele nos mostra que a loucura não é totalmente um caos imanente, pois nela operam circunstâncias ora conflituosas ora harmoniosas. A respeito disto ele afirma que "[...] a loucura só tem sentido e valor no próprio campo da razão" (idem, p.33), ou seja, sendo uma

\footnotetext{
${ }^{11}$ Hieronymus Bosch foi um importante pintor holandês. Nasceu em 1450, na cidade de Hertongenbosh e morreu em 1516. Bosch deu um grande destaque ao imaginário, retratando os medos, problemas psicológicos, criaturas imaginárias (humanos e animais) e cenas de horrores. Disponível em:

http://www.suapesquisa.com/pesquisa/bosch.htm.
} 


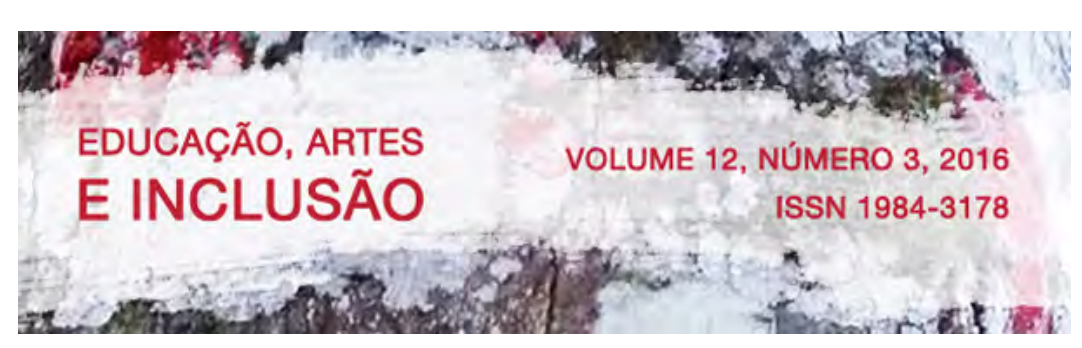

forma da razão, como analisado pelo autor, a loucura utiliza subsídios desta para se manter viva e forte. Portanto, a loucura e a razão nutrem uma relação eternamente reversível, em que uma age como uma força que controla, uniformiza e a outra como uma força que rompe, ultrapassa limites.

Fortalecendo essa proposição, Foucault (1972) levanta duas perspectivas sob as quais a loucura pode ser percebida:

[...] de um lado, uma "loucura louca" que recusa essa loucura própria da razão e que, rejeitando-a, duplica-a e nesse desdobramento cai na mais simples, na mais fechada, na mais imediata das loucuras; por outro lado, uma "loucura sábia" que acolhe a loucura da razão, ouve-a, reconhece seus direitos de cidadania e se deixa penetrar por suas forças vivas, com isso protegendo-se da loucura, de modo mais verdadeiro do que através de uma obstinada recusa sempre vencida de antemão (FOUCAULT, 1972, p.36).

Voltando um pouco, podemos comparar essa "loucura louca" à loucura estado de cegueira, e a "loucura sábia" ao louco enquanto detentor da verdade visto pela ótica literária, apresentada por Foucault (1972) a respeito da diferença entre a loucura e o louco. No entanto, não nos precipitemos, pois na literatura a personagem do louco muitas vezes ganha essa conotação de detentor da verdade, da "razão", quando, em verdade, a obra em que ele está inserido é uma sátira social. Como assinalado por Foucault (1972), é comum nessas obras a figura do louco ao mesmo tempo receber esse "privilégio" e ser ridicularizado pelo simples fato de ter razão, pois as outras personagens não lhe dão o devido valor, justamente por ser o louco da história, mostrando-nos, então, o processo de exclusão.

Prosseguindo no caminho da loucura, Foucault (1972), sob o prisma do pensamento cartesiano, evidencia e problematiza a teoria levantada pelo racionalismo. Descartes, ao afirmar sua teoria, põe de lado a figura do louco, contribuindo no processo de exclusão deste indivíduo. Dentro do pensamento cartesiano, a loucura é uma condição da impossibilidade do pensamento, como observa Foucault (1972). O ato de pensar não é considerado próprio do louco, pelo contrário, quem pensa nunca vai ser louco, considerando-se a perspectiva cartesiana. 


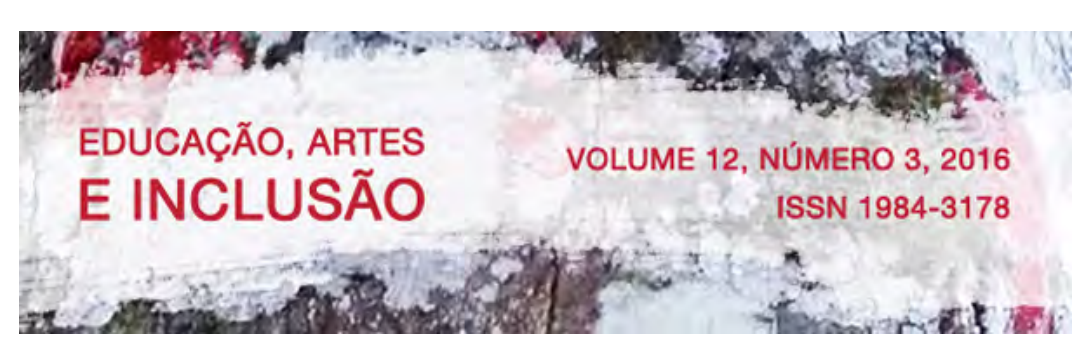

As casas de internamento não abrigavam somente os loucos. Podia-se encontrar além de seus muros todos os tipos de pessoas, conforme relata Foucault (1972). O autor aponta que uma das finalidades, senão a principal, destes espaços era livrar as cidades da miséria e da pobreza, por isso a população pobre das cidades europeias era ali recolhida e alojada. Mais tarde, essas casas de internamento passaram por uma reforma. Em 1656, é fundado em Paris o Hospital Geral, que por sinal nada tem de estabelecimento médico, servindo mais como uma estrutura semijurídica, encarregada de manter bem longe da cidade aqueles que poderiam "ferir a ordem e bem-estar da sociedade", conforme explica Foucault (1972). De acordo com o autor, o Hospital Geral servia aos propósitos da monarquia e burguesia, agindo como uma terceira ordem da repressão, pois o rei conferiu a esta instituição poderes de autoridade. Quem estivesse no comando do Hospital Geral podia exercer seus poderes não apenas na instituição como também em toda a cidade de Paris.

Como assinalado por Foucault (1972), 32 cidades do interior apresentavam essa estrutura de ordem monárquica e burguesa, ganhando força em todo território francês, às vésperas da Revolução Francesa. Não indiferente a esse movimento, a Igreja “[...] reforma suas instituições hospitalares, redistribui os bens de suas fundações; cria mesmo congregações que se propõem finalidades análogas às dos hospitais gerais" (FOUCAULT, 1972, p.51). Grande parte das casas de internamento do país eram, notadamente, mantidas por ordens religiosas, no entanto, a monarquia e a burguesia influíam no controle destes estabelecimentos. As casas de internamento agiam sob dicotomias versadas ora por princípios religiosos ora por princípios monárquicos/burgueses, misturando, muitas vezes, “[...] os velhos privilégios da Igreja na assistência aos pobres e na preocupação burguesa de pôr em ordem o mundo da miséria" (FOUCAULT, 1972, p.53).

Envolto num contexto absolutista, pré-revolução francesa, o internamento ao contrário da época da lepra, passa a ter significados políticos, sociais, religiosos, econômicos e morais, conforme descreve Foucault (1972).

O fenômeno do internamento alastra-se por toda a Europa, não muito diferente do que fora pregado em Paris, servindo, de um lado, como uma entidade repressora, punindo e "limpando" as cidades da pobreza e miséria, e, por outro, como uma entidade caridosa, ajudando os mais necessitados, abrigando-os e alimentando-os, segundo a pesquisa de Foucault (1972). 


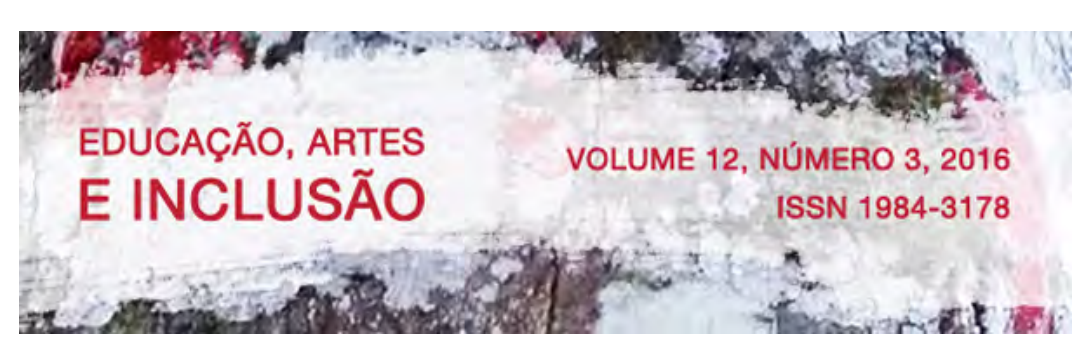

Durante um longo tempo, a miséria sobressaltou sobre as questões da loucura, tanto que esta passa a ser entendida como uma condição quase indissociável daquela. A loucura era considerada, muitas vezes, como um estado de "vagabundagem", ociosidade e, em outras circunstancias, incapacidade de diversos tipos e maneiras, como podemos ver nos estudos de Foucault (1972). Conforme o autor, assim como já foi dito nesta seção, a miséria não é mais vista pela ótica da humilhação e necessidade de ajuda ou caridade, mas como um castigo, sinal da maldição invocada pelo descontentamento do Senhor, ou seja, a miséria carrega consigo uma conotação religiosa/espiritualista, recebendo um status negativo perante a sociedade que a cerca.

Essa significação despojada sobre a pobreza deve-se, entre outros fatores, ao fato de que na época da Renascença, período da Reforma Protestante, pré-Revolução Francesa e até a Revolução Francesa, o número de pessoas na margem da pobreza e miséria era bem acentuado e como o governo da época não queria, e/ou não podia, bancar as despesas dessa classe, utilizou-se de subterfúgios para se isentar dessa responsabilidade. No entanto, essa "isenção" não se consolidou de fato, pois para acabar com a pobreza seria necessário investir em atitudes que promovessem uma "mobilidade social". Porém, como pudemos analisar na obra de Foucault (1972), isso social não aconteceu. O que houve foi, digamos, um aproveitamento dessa classe a favor da economia da cidade. Aos pobres foi estabelecido trabalho forçado e incutido um pensamento de não caridade para com eles, tornando, por consequência, a prática da esmola um ato condenável.

“A partir da era clássica e pela primeira vez, a loucura é percebida através de uma condenação ética da ociosidade e numa imanência social garantida pela comunidade de trabalho" (FOUCAULT, 1972, p. 73). Diante do que foi explanado, o trabalho assume aqui um sentido puramente repressivo, servindo como um exercício de coação moral onde o interno tem que se "ajustar" à ordem convencionada pela sociedade vigente. A ociosidade, libertinagem e liberdade sexual (relações fora do padrão estabelecido) eram submetidas a sanções rigorosas, visto a ordem moral instituída na época. Tudo que fugisse desse padrão considerado aceitável era proibido e, portanto, condenável.

Foucault (1972) nos explica, que ao final do século XVIII, certas formas de pensamento "libertino" e as novas formas de relações sexuais, que começaram a se instaurar na época, entram para "o rol dos signos maiores da loucura" (ibidem, p.84). A sexualidade e 


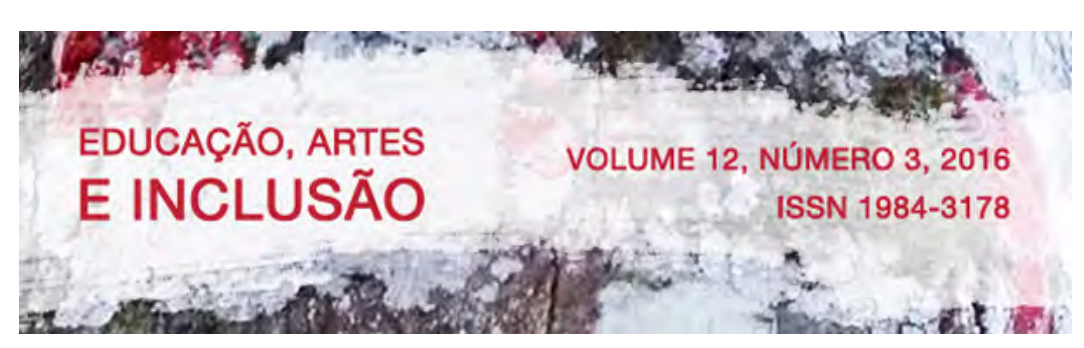

suas diversas categorias, "[...] em todos os tempos, e provavelmente em todas as culturas [...] foi integrada num sistema de coações [...]" (FOUCAULT, 1972, p. 90). Conforme o autor, a sexualidade foi dividida entre a Razão e o Desatino, compreendendo de tal modo, as relações extraconjugais, a homossexualidade e a prostituição dentro desta segunda classe. $\mathrm{O}$ internamento neste contexto surge como a maneira pela qual o homem iria se expurgar da devassidão, segundo Foucault (1972).

Fica claro, para nós, que o louco, na melhor das hipóteses, configura-se como um indivíduo transgressor, isto é, se o considerarmos como um ser que não se subjuga a normas e regras instituídas por uma sociedade, que diz o que é certo ou errado sob uma ideologia dominante, que age conforme seus próprios princípios para “organizar” a sociedade.

No entanto, com os avanços científicos, a loucura, que antes era julgada sob questões puramente morais, sociais, religiosas, econômicas e políticas, passa a ser estudada, então, sob a ótica da patologia. E a partir dessa perspectiva a medicina assume o posto que "[...] garantirá a possibilidade de apropriação da loucura como seu objeto de conhecimento" (FRAYZE-PEREIRA, 1984, p.83).

Essa nova tomada de consciência proporcionou uma ressignificação do espaço no qual o louco era despejado. A casa de internamento que de tempos em tempos era ressignificada, denominada agora de asilo, desempenhava neste contexto um "tratamento humanizado". Contudo, conforme Frayze-Pereira (1984) ao referir-se sobre os estudos de Tuke (1813), por mais que pregassem um "tratamento humanizado", os asilos não poupavam práticas coercitivas "[...] tais como ameaças e punições as mais diversas, privações alimentares, humilhações" (FRAYZE-PEREIRA, 1984, p.84).

Não muito diferente, os hospitais asilares e instituições que se dedicavam ao tratamento da saúde mental, aqui no Brasil, por muito tempo, experienciaram trabalhos como esses. Entretanto, na tentativa de mudar a realidade precária da psiquiatria nacional, Nise da Silveira investiu em uma abordagem verdadeiramente humanista, proporcionando aos seus pacientes uma experiência libertadora, fora das agruras de uma internação opressora. Sobre as contribuições do trabalho da psiquiatra, traremos a abordagem da terapêutica ocupacional, compreendendo, brevemente, seus processos e perspectivas, além de pôr em xeque o conceito de arte empreendido por Tatarkiewicz, que abordamos anteriormente. 


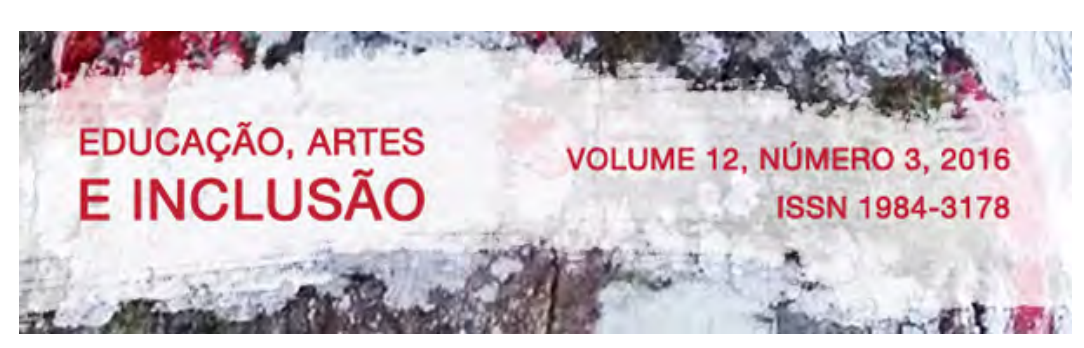

\section{NISE DA SILVEIRA E SUAS CONTRIBUIÇÕES}

Avessa aos métodos psiquiátricos instituídos em sua época, meados dos anos 40, (eletrochoque, coma insulínico e lobotomia), Nise da Silveira, desenvolveu um trabalho rico e instigante, que influenciou a psiquiatria, especialmente a Terapia Ocupacional, nacional e internacional no que diz respeito ao tratamento da loucura. O trabalho desenvolvido pela psiquiatra alagoana propõe que a loucura seja encarada não mais com uma indiferença, que se configura quando vista sob a ótica da doença, mas como inumeráveis estados do ser ${ }^{12}$, levando em consideração a própria existência do louco e suas angústias.

Essa indiferença, que compreende a loucura como uma doença, submete o louco a um estado objetificado, caracterizando-o como "algo" que não sente as pressões a sua volta, não se constituindo como um ser humano que de fato é. Corroborando essa visão, o modelo médico vigente na época era pautado no racionalismo, posto que empreendia uma "[...] divisão entre mente e corpo, típica da filosofia de Descartes, caracterizando o ser humano como uma máquina e a doença mental como um desajuste dessa máquina, que necessita de reparos" (MELO, 2009, p. 39). Desse modo, essa visão desconsidera a complexidade inerente ao ser humano. Em Melo (2009) vemos claro o quão Nise da Silveira era contrária a esse tipo de pensamento. Para a psiquiatra, o ser humano não deve ser concebido a partir de partes e muito menos o doente mental como um feixe de sintomas.

Até Nise da Silveira assumir a seção de Terapêutica Ocupacional do Centro Psiquiátrico Pedro II, no Rio de Janeiro, as atividades praticadas no setor eram em grande parte de cunho higiênico, uma vez que os internos ficavam a cargo da limpeza do espaço, das roupas, etc., consideradas pela psiquiatra, de acordo com os estudos de Melo (2009), como atividades que envolvem "o esforço característico do trabalho" (SILVEIRA, 1966 apud MELO, 2009, p. 45). Mais tarde, assumindo a direção do setor, ela abandona essas atividades e introduz atividades expressivas, tais como pintura e modelagem, citando apenas algumas, com a pretensa intenção de entrar em contato com o mundo dessas pessoas enclausuradas nesse internamento, conforme Melo (2009).

\footnotetext{
${ }^{12}$ Conceito defendido por Antonin Artaud, "poeta e teatrólogo francês que esteve por vários anos internado em hospitais psiquiátricos" (JUNIOR, 2010, p. 183).
} 


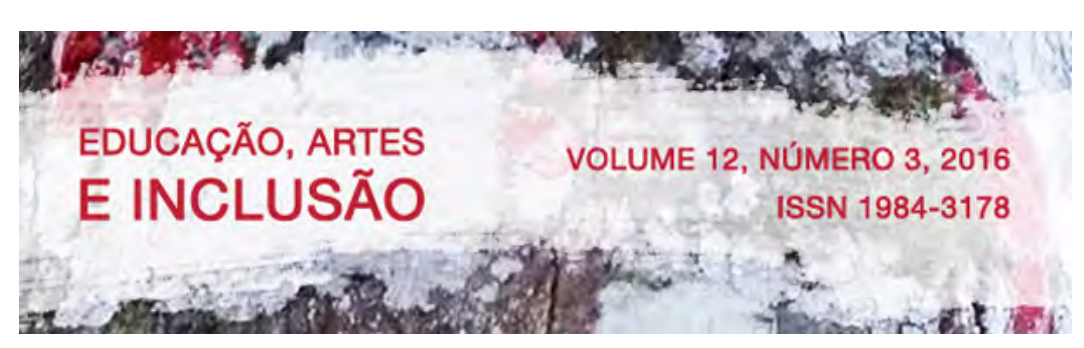

Proporcionar aos pacientes um trabalho expressivo, em que eles, por meio da pintura e modelagem, plasmam seus sentimentos e percepção de mundo, contrapõe-se à vertente que pensa que estas pessoas não possui a capacidade de pensamento, pois nessas atividades eles externalizam seus modos de perceber o mundo a sua volta, confirmando a concepção dos vários estados do ser, noção arrolada anteriormente.

De acordo com Walter Melo Junior, “[...] a psiquiatria afetiva de Nise da Silveira pressupõe que, para se criar condições terapêuticas favoráveis, o ambiente deve ser acolhedor e sem qualquer tipo de coação [...]" (JUNIOR, 2010, p. 182). Desse modo, o trabalho da psiquiatra pautava-se sob a relação de afeto entre terapeuta e paciente, dando-lhe maior liberdade, minimizando, por consequência, a hierarquia de poderes de dominação tão presentes no universo psiquiátrico até então.

Mantendo base nas contribuições da Psicologia Analítica desenvolvida por Jung ${ }^{13}$, conforme apontam Carvalho e Amparo (2006), a psiquiatra percebeu que a prática criadora de imagens mostrava-se terapêutica em si mesma, visto que o ato de pintar adquiria qualidades terapêuticas. Conforme Nise da Silveira, nos estudos de Castro e Lima (2007):

As imagens do inconsciente, objetivadas na pintura, tornavam-se passíveis de certa forma de trato, mesmo sem que houvesse nítida tomada de consciência de suas significações profundas. Lidando com elas, plasmandoas com suas próprias mãos, o doente as via, agora, menos apavorantes e, mais tarde, até inofensivas. Ficavam despojadas de suas fortes e desintegrantes cargas energéticas (SILVEIRA, s/d, p.32 apud idem, p. 370).

Ao encontrar meios de expressão que possibilitam a materialização de suas imagens do inconsciente, o louco estaria aproximando-se mais do consciente, reorganizando, por sua vez, seu mundo interno e restaurando, por conseguinte, sua relação com o mundo exterior.

Para a realização de um trabalho eficiente e consistente, no que concerne ao aprofundamento teórico, Nise da Silveira buscou articular diversas áreas do conhecimento como por exemplo, psicologia, literatura, religião, mitologia, artes plásticas e filosofia na

\footnotetext{
${ }^{13}$ Psiquiatra suíço, fundador da Psicologia Analítica. Jung construiu as bases da psicologia analítica, desenvolvendo a teoria dos arquétipos e incorporando conhecimentos das religiões orientais, alquimia e mitologia. Disponível em: http://educacao.uol.com.br/biografias/carl-gustav-jung.htm. Acesso em: 17 de abr. de 2016.
} 


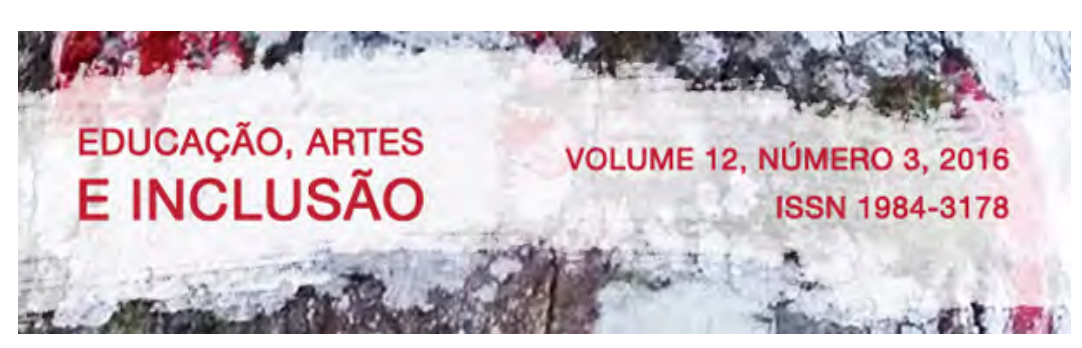

tentativa de compreender e redimensionar os estados existenciais do ser humano e a inteligibilidade do mundo.

As obras artísticas produzidas pelos internos do Centro Psiquiátrico Pedro II, coordenados por ela, desmitificam o trabalho artístico como um processo exclusivamente consciente.

\section{IMAGENS DO INCONSCIENTE}

Retomando a problemática levantada anteriormente, a respeito da definição de arte, em que questionamos o ideal defendido por Tatarkiewicz, que a rotula como uma atividade estritamente consciente, nós contrapomos esse pensamento, utilizando-nos do pressuposto de que "[...] a obra de arte é um ser de sensação [...]” (DELEUZE; GUATTARI, 2010, p. 194), independente do homem, podendo existir na ausência dele. A produção artística seria, em sua maioria, movida por ela e, no tocante às obras dos pacientes loucos, elas nos permitem conhecer o universo que permeia o inconsciente deles.

Deleuze \& Guattari explicam que nós “[...] pintamos, esculpimos, compomos e escrevemos com sensações.” (DELEUZE; GUATTARI, 2010, p.196). É a partir delas que experienciamos tudo à nossa volta e isso não seria diferente com o louco, com suas sensações aguçadas e extremamente valorizadas.

Em consonância com esse fazer artístico pautado na sensação, Deleuze \& Guattari, propõem que a arte $\operatorname{abstrata}^{14}$ e a arte conceitual $^{15}$ são verdadeiramente "sensação por sensação". Não exprimindo algo ou alguém que pode ser referenciado ou aludido ao nosso

\footnotetext{
${ }^{14}$ Em sentido amplo, abstracionismo refere-se às formas de arte não regidas pela figuração e pela imitação do mundo. Em acepção específica, o termo liga-se às vanguardas europeias das décadas de 1910 e 1920, que recusam a representação ilusionista da natureza. A decomposição da figura, a simplificação da forma, os novos usos da cor, o descarte da perspectiva e das técnicas de modelagem e a rejeição dos jogos convencionais de sombra e luz, aparecem como traços recorrentes das diferentes orientações abrigadas sob esse rótulo. Inúmeros movimentos e artistas aderem à abstração, que se torna, a partir da década de 1930, um dos eixos centrais da produção artística no século XX. Disponível em: http://enciclopedia.itaucultural.org.br/termo347/abstracionismo

${ }^{15}$ Para a arte conceitual, vanguarda surgida na Europa e nos Estados Unidos no fim da década de 1960 e meados dos anos 1970, o conceito ou a atitude mental tem prioridade em relação à aparência da obra. Disponível em: http://enciclopedia.itaucultural.org.br/termo3187/arte-conceitual. Acesso em: 17 de abr. de 2016.
} 


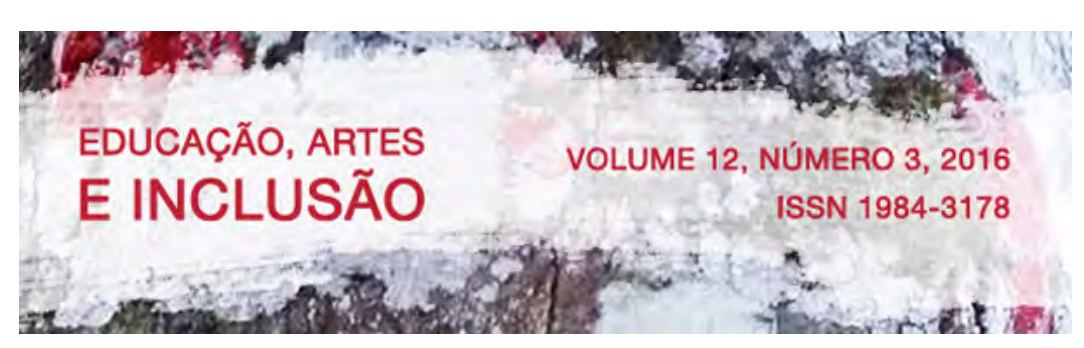

mundo, elas não mantêm uma relação de referência explícita com o que depreendemos da realidade, característica questionada por Nise da Silveira, segundo alguns autores.

Sobre o trabalho de Nise da Silveira, vemos em Carvalho e Amparo (2006), que a abstração, o geometrismo e a percepção do espaço e do tempo devem ser consideradas de maneira aberta ao tratarmos das produções artísticas dos loucos. Essa percepção de espaço e tempo baseia-se no pressuposto de que na época em que ela colocava em prática seu trabalho, o campo das ciências passava por intensa revolução e descobrimentos, pondo em xeque a noção de realidade tal como a concebemos.

Permeada por essas pesquisas, Nise da Silveira procurou desenvolver seu trabalho, buscando pôr em evidência seus questionamentos sobre o que é a realidade, o que faz uma coisa ser real para uns e não para outros, a própria constituição de sociedade e a concepção dos diferentes estados do ser.

Carvalho e Amparo (2006) esclarecem algumas das contribuições da fenomenologia para a psiquiatria, reconhecendo o papel da subjetividade e da intersubjetividade, que trazem uma nova compreensão e perspectiva para o tratamento da loucura.

Levando em consideração a subjetividade do ser, embasada na Psicologia Analítica de Jung, Nise da Silveira observou que as obras artísticas de seus pacientes revelavam uma carga simbólica muito grande. Castro e Lima, a respeito do inconsciente, falam que Jung distinguia duas esferas na psique inconsciente: “[...] um inconsciente pessoal relacionado à história pessoal de cada indivíduo, e um inconsciente coletivo, que compõe um elo e um vínculo entre o indivíduo e a humanidade" (CASTRO; LIMA, 2007, p. 370). Os autores suscitam que para Jung a produção de imagens, fantasias e delírios são as expressões pelas quais nós melhor reconhecemos os símbolos elaborados pelo e no consciente.

É frequente nas obras dos artistas (pacientes) “[...] qualidades arcaicas, que indicam a natureza das forças criativas que lhes estão subjacentes" (SCHINCARIOL, 2000, p. 13), assemelhando-se com obras de outros períodos históricos e civilizações anteriores a nossa, tais como a civilização Egípcia, Indo-persa e, Grega. Podemos fazer um comparativo das obras produzidas pelos artistas entre as obras dessas civilizações. 

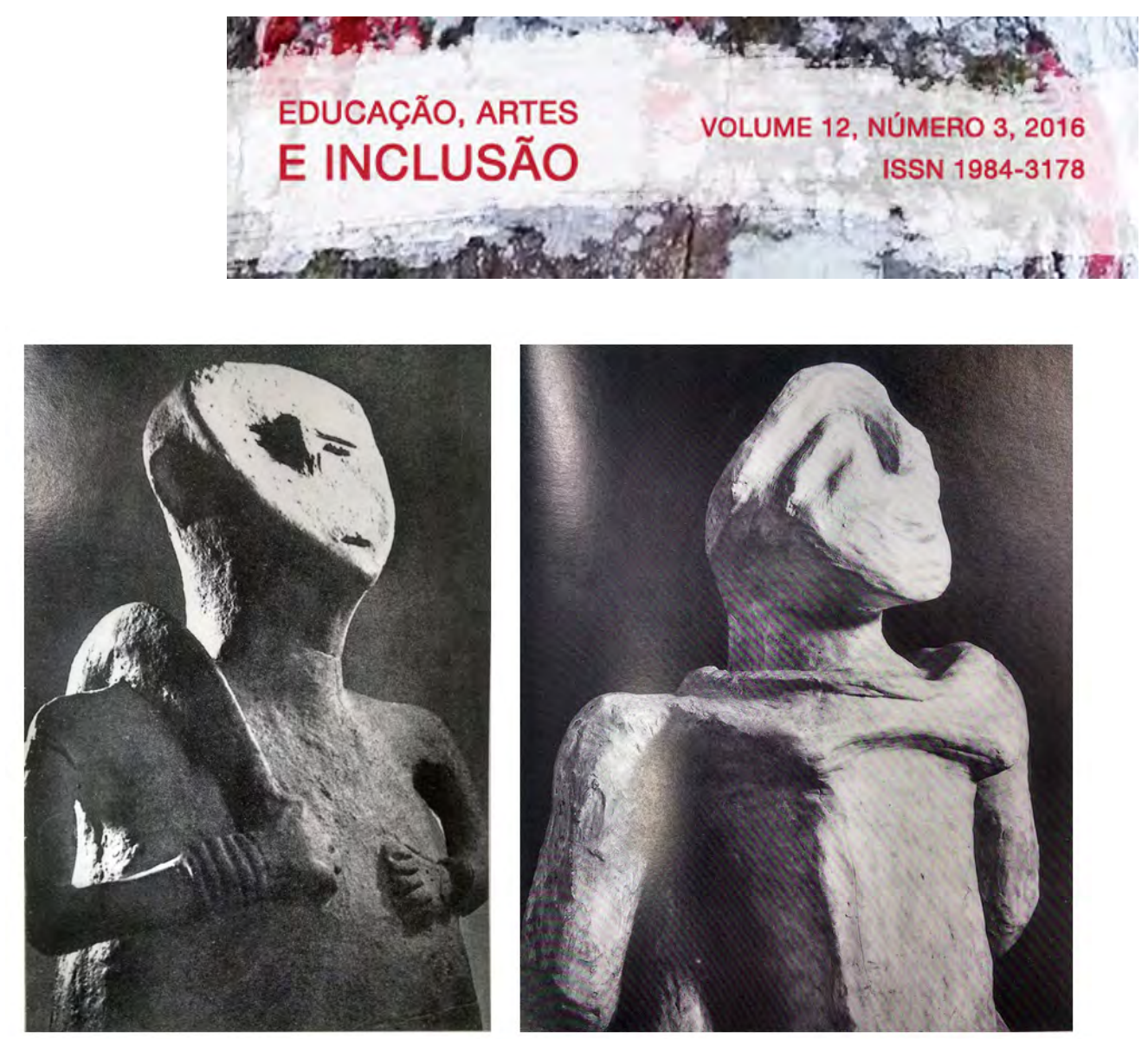

Figura 1- Estatueta da cultura Tisza (à esquerda); Cópia em gesso de modelagem em barro, 1950, de Adelina Gomes (à direita). Fonte: Catálogo Arqueologia da Psique, 2000.

Na Figura 1, à esquerda, escultura datada de 5000 a.C. da cultura Tisza e à direita obra de Adelina Gomes, modelagem em barro, que mantém pontos de semelhança com a outra obra, como é perceptível.
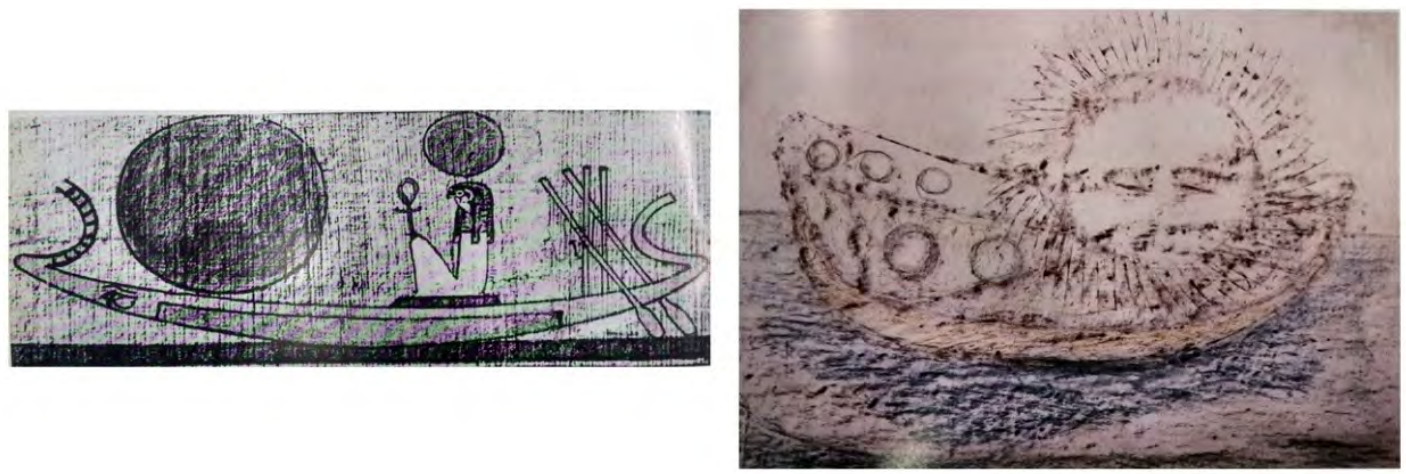

Figura 2- Deus Rá e a Barca do Sol, detalhe de um papiro da 19ª Dinastia Egípcia (à esquerda); A Barca do sol (1976), lápis de cera sobre papel, Carlos Pertuis (à direita). Fonte: Catálogo Arqueologia da Psique, 2000. 


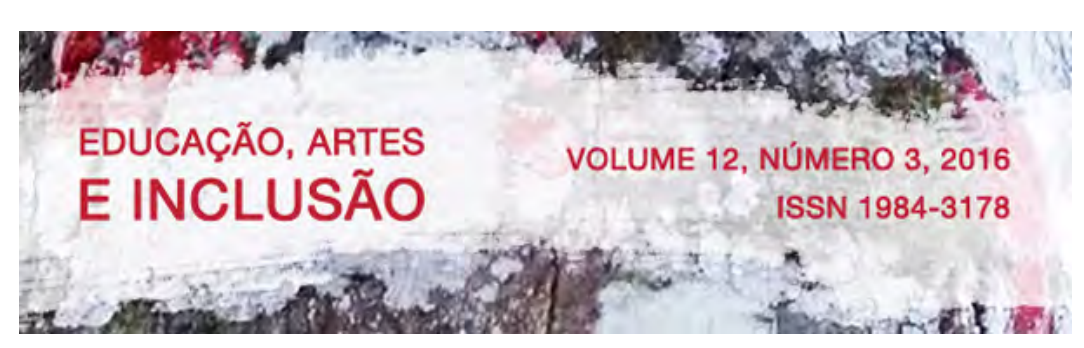

(DELEUZE; GUATTARI, 2010, p. 208), não se limitando somente a isso, pois, segundo os autores pesquisados, a arte permite ao indivíduo o encontro consigo mesmo, promovendo a relação entre ele e o mundo externo e possibilitando sua integração ao meio social.

Uma proposta que visa à integração do indivíduo com deficiência intelectual ao meio social é a escola, pois como afirma Mello (1997) “[...] o primeiro passo para a integração social passa pela escola, já que o papel dela não é apenas o de ensinar cadeiras acadêmicas [...] mas também o de participar decisivamente no estabelecimento dos padrões de convivência social” (MELLO, 1997, p. 14). Para o autor, é na escola, não exclusivamente, que a criança e/ou jovem estabelecerá contato com outras pessoas, criará laços de amizade, experienciará momentos que definirão quem ele será futuramente.

Pensando no aluno com deficiência intelectual, Veltrone e Mendes (2012), colocam que, a política da educação inclusiva deve atender concomitantemente, este aluno, no Atendimento Educacional Especializado (AEE) e na classe comum da escola regular. As autoras também abordam que a nomenclatura hoje conhecida como deficiência intelectual variou ao longo dos tempos e a literatura científica brasileira sempre evidenciou a dificuldade nos procedimentos de identificação desse alunado para a definição, elegibilidade e encaminhamento aos serviços especializados.

Em relação às instituições escolares, Gomes; et al, (2007), destacam que estas ainda estão presas aos moldes tradicionais, autoritários e conservadores, mostram-se muitas vezes permeadas por pré-conceitos que as fazem assumir uma postura excludente, quando se diz inclusiva. Para os autores “[...] ao invés de adaptar e individualizar/diferenciar o ensino para alguns, a escola comum precisa recriar suas práticas, mudar suas concepções, rever seu papel, sempre reconhecendo e valorizando as diferenças" (GOMES; ET AL, 2007, p.17). A escola, os professores e toda comunidade escolar devem possibilitar desafios, desenvolvendo a criticidade e a autonomia, contribuindo, assim, na formação do aluno como ser humano.

\section{CONSIDERAÇÕES FINAIS}

Ao longo desta pesquisa, discutimos sobre a definição de arte e percebemos o quão é arbitrário e subjetivo qualquer conceituação sobre a arte, o objeto artístico e até mesmo o 


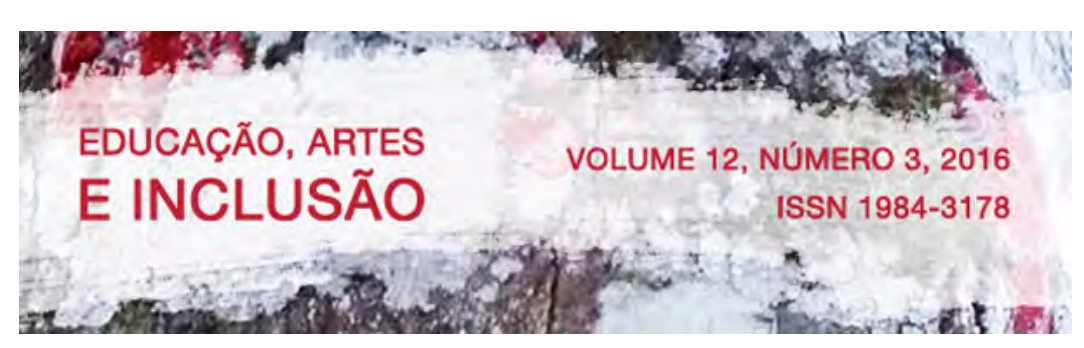

próprio fazer artístico. Como aferido, a arte deve ser percebida como um processo histórico, cultural e social. Sendo assim, deve-se levar em consideração todos os aspectos que envolvem as produções artísticas de todas as épocas.

Foi a partir da problematização dos conceitos de arte apresentados nesta pesquisa, que suscitamos uma reflexão sobre as produções artísticas feitas por pessoas diagnosticadas como loucas, reconhecendo e valorizando o valor artístico e estético de suas produções.

Ao contrário dos conceitos expostos no trabalho, percebemos que desconsiderar as produções artísticas destas pessoas é reiterar o processo de exclusão ao qual elas são submetidas. Limitar o nosso olhar perante suas obras somente pelo prisma da patologia é corroborar com uma visão preconceituosa, demarcando, assim, limites aos quais elas não podem e nem devem estar sujeitas.

Sobre essas barreiras que são impostas aos indivíduos com deficiência intelectual, nós trouxemos à luz um importante debate sobre inclusão, que tem sido comumente discutido em pesquisas e meios comunicativos (jornais, revistas, internet, etc.), mas que pouco tem sido posto em prática na realidade. Apesar de já termos documentos legais que amparam os direitos dessas pessoas, compreendemos que ainda pairam dúvidas, incertezas e inseguranças quanto à prática inclusiva na sociedade, começando pela escola.

Não é pretensão nossa apresentar um trabalho "fechado". O objetivo é promover um debate, uma reflexão sobre o assunto, colaborando e proporcionando muitos outros estudos para auxiliar no trabalho dos agentes educacionais e também no reconhecimento e valoração da deficiência intelectual, percebendo-os como seres humanos e não como um aglomerado de sintomas.

\section{REFERÊNCIAS}

ABSTRACIONISMO. In: ENCICLOPÉDIA Itaú Cultural de Arte e Cultura Brasileiras. São Paulo: Itaú Cultural, 2016. Disponível em: $<$ http://enciclopedia.itaucultural.org.br/termo347/abstracionismo $>$. Acesso em: 17 de maio 2016. Verbete da Enciclopédia. ISBN: 978-85-7979-060-7. 


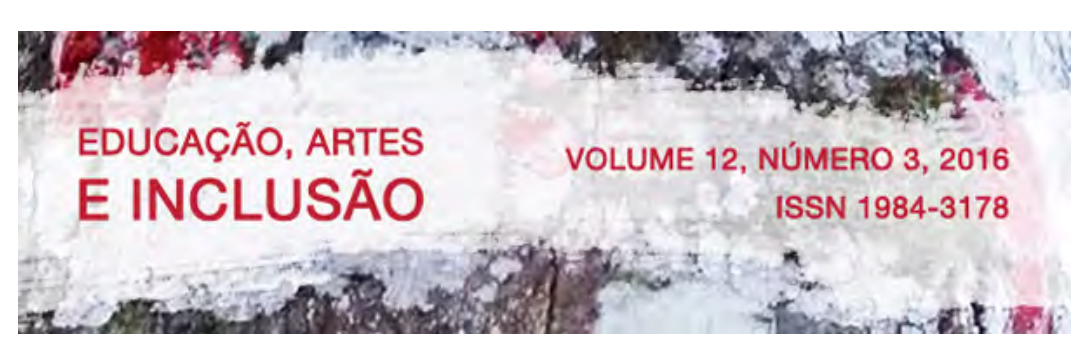

ARTE Conceitual. In: ENCICLOPÉDIA Itaú Cultural de Arte e Cultura Brasileiras. São Paulo: Itaú Cultural, 2016. Disponível em:

$<$ http://enciclopedia.itaucultural.org.br/termo3187/arte-conceitual $>$. Acesso em: 17 de maio 2016. Verbete da Enciclopédia. ISBN: 978-85-7979-060-7.

BARBOSA, A. M. Arte-Educação no Brasil: realidade hoje e expectativas futuras. Estudos avançados, v. 3, n. 7, p. 170-182, 1989.

Recorte e colagem: influências de John Dewey no ensino de arte no Brasil. São Paulo: Cortez, 1982.

(org.). Ensino da arte: memória e história. São Paulo: Perspectiva, 2008.

(org.). Arte/educação contemporânea: consonâncias internacionais. 2. ed. São Paulo:

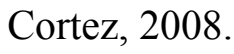

(org.). Arte-educação: leitura no subsolo. 9. ed. São Paulo: Cortez, 2013.

BRASIL. Lei 5.692, de 11 de agosto de 1971. Fixa Diretrizes e Bases para o ensino de $1^{\circ}$ e $2^{\circ}$ graus, e dá outras providências. Brasília, DF: 1971.

BRASIL. Parâmetros curriculares nacionais: arte. Secretaria de Educação Fundamental. Brasília: MEC/SEF, 1998. (5º $8^{\circ}$ séries).

CARVALHO, S. M. M. de; AMPARO, P. H. M. Nise da Silveira: a mãe da humanaidade. Revista Latinoamericana de Psicopatologia Fundamental, v. 9, n. 1, p. 126-137, 2006.

CASTRO, E. D. de; LIMA, E. M. F. de A. Resistência, inovação e clínica no pensar e no agir de Nise da Silveira. Interface (Botucatu), Botucatu, v. 11, n. 22, p. 365-376, ago. 2007.

Disponível em: $<$ http://www.scielo.br/scielo.php?script=sci_arttext\&pid=S141432832007000200017\&lng=en\&nrm=iso $>$. Acessado em: 14 abr. 2016.

CHEVALIER, J.; GHEERBRANT, A. Dicionário de símbolos: (mitos, sonhos, costumes, gestos, formas, figuras, cores, números). 27. ed. Rio de Janeiro: José Olympio, 2015.

COLI, J. O que é arte. 15. ed. São Paulo: Brasiliense, 1995. (Primeiros Passos, 46).

DADAÍSMO. In: ENCICLOPÉDIA Itaú Cultural de Arte e Cultura Brasileiras. São Paulo: Itaú Cultural, 2016. Disponível em:

$<$ http://enciclopedia.itaucultural.org.br/termo3651/dadaismo $>$. Acesso em: 17 de maio 2016. Verbete da Enciclopédia. ISBN: 978-85-7979-060-7

DELEUZE, Gilles; GUATTARI, Félix. O que é Filosofia? São Paulo: Editora 34, 2010.

EISNER, E. Estrutura e mágica no ensino da Arte. In: BARBOSA, A. M. Arte-educação: leitura no subsolo. 9. ed. São Paulo: Cortez, p. 111-129, 2013. 


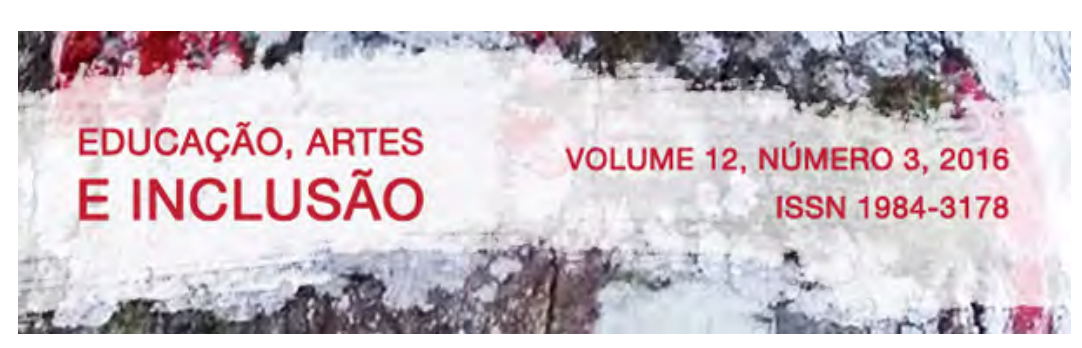

FERRAZ, M. H. C. de T.; FUSARI, M. F. de R. Arte na educação escolar. São Paulo: Cortez, 1992.

FISCHER, E. A função da arte. In: A necessidade da arte. 9. ed. Rio de Janeiro: LTC, p. 11-20, 2014.

FOUCAULT, M. História da loucura da Idade Clássica. São Paulo: Perspectiva, 1972. (Estudos, 61).

FRAYZE-PEREIRA, J. A. Nise da Silveira: imagens do inconsciente entre psicologia, arte e política. Estud. Av., São Paulo, v. 17, n. 49, p. 197-208, dez. 2003. Disponível em: $<$ http://www.scielo.br/scielo.php?script=sci_arttext\&pid=S0103$40142003000300012 \& \operatorname{lng}=$ en\&nrm=iso $>$. Acessado em: 14 abr. 2016.

O que é loucura. 3. ed. São Paulo: Brasiliense, 1984. (Primeiros Passos, 73).

HYERONIMUS Bosch. 2004. Disponível em:

$<$ http://www.suapesquisa.com/pesquisa/bosch.htm>. Acesso em: 20 jun. 2016.

GOMES, A. L. L. Deficiência mental. São Paulo: MEC/SEESP, 2007.

JUNIOR, W. M. Nise da Silveira, Antonin Artaud e Rubens Corrêa: Fronteiras da Arte e da Saúde Mental. Gerais: Revista Interinstitucional de Psicologia, São João Del-Rei, p. 182$191,2010$.

MELO, W. Nise da Silveira e o campo da Saúde Mental (1944-1952): contribuições, embates e transformações. Mnemosine, Rio de Janeiro, v.5, n. 2, p. 30-52, 2009.

MELLO, A. M. S. R. de. Autismo e Integração. In: MANTOAN, M. T. E. (org.). A integração de pessoas com deficiência. São Paulo: Menmnon/SENAC, p. 13-17, 1997.

MELLO, L. C. Flores do Abismo. Disponível em:

$<$ http://www.museuimagensdoinconsciente.org.br/index.html $>$. Acesso em: 08 nov. 2014.

READ, H. O sentido da arte. 4. ed. São Paulo: IBRASA, 1978.

RIZZI, M. C. de S. L. Reflexões sobre a Abordagem Triangular do Ensino da Arte. In: BARBOSA, A. M. (org.). Ensino da arte: memória e história. São Paulo: Perspectiva, p. 335-348, 2008.

SCHINCARIOL, G. (coord.). Arqueologia da Psique - Exposição Museu de imagens do inconsciente. Rio de Janeiro. 2000.

SCHWARTZMAN, J. S. Integração: do que e de quem estamos falando. In: MANTOAN, M. T. E. (Org.). A integração de pessoas com deficiência. São Paulo: Menmnon/SENAC, p. 6266, 1997. 


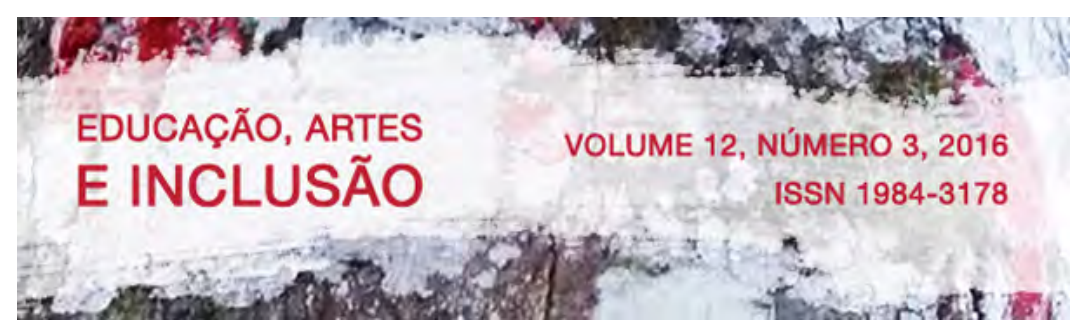

TATARKIEWICZ, W. A definição disjuntiva da arte. British Journal of Aesthetics, p. 147$150,1971$.

VELTRONE, Aline Aparecida; MENDES, Enicéia Gonçalves. Impacto da mudança de nomenclatura de deficiência mental para deficiência intelectual. Revista Educação em Perspectiva, Viçosa, v. 3, n. 2, p. 448-450, jul./dez. 2012. Disponível em:

http://www.seer.ufv.br/seer/educacaoemperspectiva/index.php/ppgeufv/article/viewFile/235/9 1. Acesso em: 07 out. de 2016.

Recebido em 26 de julho de 2016 Aprovado em 9 de outubro de 2016 